\title{
SARS-CoV-2 ile Illgili Farklı Prensipli Ticari Antikor Testlerinin COVID-19 Hastalarındaki Tanısal Performanslarının Değerlendirilmesi
}

\section{Evaluation of the Diagnostic Performance of Different Principles of SARS-CoV-2 Commercial Antibody Tests in COVID-19 Patients}

\author{
Harika Öykü DiNÇ (ID), Yusuf Emre ÖZDEMIR²(ID), Sena ALKAN(ID), \\ Zeynep GÜNGÖRDÜ DALAR ${ }^{4}(I D)$, Nesrin GAREAYAGHi ${ }^{5}(I D)$, Serhat $\operatorname{SiREKBASAN}^{6}($ ID),

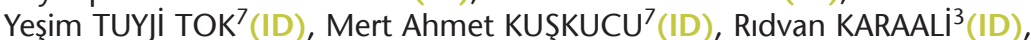

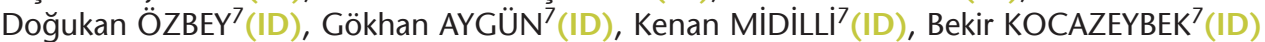 \\ ${ }^{1}$ Bezmialem Vakıf Üniversitesi Eczacılık Fakültesi, Farmasötik Mikrobiyoloji Anabilim Dalı, İstanbul. \\ ${ }^{1}$ Bezmialem Vakıf University Faculty of Pharmacy, Department of Pharmaceutical Microbiology, istanbul, Turkey. \\ ${ }^{2}$ Bakırköy Dr. Sadi Konuk Eğitim ve Araştırma Hastanesi, Enfeksiyon Hastalıkları ve Klinik Mikrobiyoloji Kliniği, İstanbul. \\ ${ }^{2}$ Bakırköy Dr. Sadi Konuk Research and Training Hospital, Clinic of Infectious Diseases and Clinical Microbiology, \\ Istanbul, Turkey. \\ 3 İstanbul Üniversitesi-Cerrahpaşa, Cerrahpaşa Tıp Fakültesi, Enfeksiyon Hastalıkları ve Klinik Mikrobiyoloji Anabilim Dalı, \\ istanbul. \\ ${ }^{3}$ Istanbul University-Cerrahpasa, Cerrahpaşa Faculty of Medicine, Department of Infectious Diseases and Clinical Microbiology, \\ Istanbul, Turkey. \\ 4 ìstanbul Altınbaş Üniversitesi Tıp Fakültesi, Tıbbi Mikrobiyoloji Anabilim Dalı, İstanbul. \\ ${ }^{4}$ Istanbul Altinbas University Faculty of Medicine Department of Medical Microbiology, Istanbul, Turkey. \\ ${ }^{5}$ Şişli Hamidiye Etfal Eğitim ve Araştırma Hastanesi, Kan Merkezi, İstanbul. \\ 5 Istanbul Sisli Hamidiye Etfal Training and Research Hospital, Blood Center, Istanbul, Turkey. \\ ${ }^{6}$ Çankırı Karatekin Üniversitesi, Eldivan Sağlık Hizmetleri Meslek Yüksek Okulu, Tıbbi Hizmetler ve Teknikler Bölümü, \\ Çankırı. \\ ${ }^{6}$ Çankırı Karatekin University, Eldivan Vocational School of Health Services Department of Medical Laboratory Techniques, \\ Çankırı, Turkey. \\ 7 İstanbul Üniversitesi-Cerrahpaşa, Cerrahpaşa Tıp Fakültesi, Tıbbi Mikrobiyoloji Anabilim Dalı, İstanbul. \\ ${ }^{7}$ Istanbul University-Cerrahpasa, Cerrahpaşa Faculty of Medicine, Department of Medical Microbiology, Istanbul, Turkey.
}

Makale Atıfı: Dinç HÖ, Özdemir YE, Alkan S, Güngördü Dalar Z, Gareayaghi N, Sirekbasan S ve ark. SARS-CoV-2 ile ilgili farklı prensipli ticari antikor testlerinin COVID-19 hastalarındaki tanısal performanslarının değerlendirilmesi. Mikrobiyol Bul 2021;55(2):207-222.

\section{ÖZ}

Şiddetli akut solunum sendromu koronavirüs-2 (SARS CoV-2)'nin ortaya çıkmasının ve tanıda yalnız polimeraz zincir reaksiyonu (PCR) kullanılmasının ardından, antikor testleri hızla çeşitli ticari firmalar tarafından geliștirilmiştir. Farklı viral hedef proteinleri ve antikor alt sınıflarını saptayan bu testlerin, duyarlıık ve özgüllüğü de farklıık göstermektedir. Çalışmada, testlerin tanı amaçlı kullanımını değerlendirmek için çeşitli firmaların (Abbott, Roche, Euroimmun, Dia.Pro, Anshlabs, Vircell, UnScience ve 
RedCell) farklı prensiplere sahip (ECLIA/CLIA, EIA, LFA) SARS-CoV-2 IgM, IgA ve IgG testlerinin duyarlılık ve özgüllük başta olmak üzere tanısal performanslarının incelenmesi amaçlanmıştır. İstanbul ÜniversitesiCerrahpaşa (IÜC), Cerrahpaşa Tıp Fakültesi (CTF) Hastanesi, Pandemi Polikliniğine COVID-19 şüphesi ile başvuran, sonrasında COVID-19 klinik ve moleküler tanısı almış, 180 akut ve 180 geçirilmiş COVID-19 hastası çalışmamıza dahil edilmiştir. Semptomların başlangıcından itibaren ilk üç hafta içerisinde alınan hastalar akut hasta grubuna, üçüncü hafta ve sonrasında alınan hastalar geçirilmiş hasta grubuna dahil edilmiştir. Nisan-Haziran 2018 tarihleri arasında COVID-19 pandemisi öncesinde, Şişli Hamidiye Etfal Eğitim ve Araştırma Hastanesi, Kan Merkezi biriminden temin edilen 180 serum örneği kontrol grubu olarak çalışmaya dahil edilmiştir. Bu çalışmaya dahil edilen tüm testler üretici firmaların önerileri doğrultusunda çalışıımıştır. COVID-19 geçirmiş hastalarda farklı prensiplere sahip IgG saptayan testler arasında en etkili testlerin duyarlıık ve özgüllük değerleri sırasıyla \%86.7/\%99.4 (Abbott), \%86.1/\%98.9 (Dia. Pro), \%91.3/\%95 (RedCell)'tir. Akut COVID-19 hastalarında farklı prensiplere sahip IgM saptayan testler arasında ise duyarlılık ve özgüllük değerleri sırasıyla \%67.8/\%99.4 (Abbott), \%68.9/\%98.6 (Vircell), \%50/\%97.5 (RedCell)'tir. Akut COVID-19 hastalarında en iyi uyumu 0.67 kappa katsayısı ile Abbott IgM ve 0.65 kappa katsayısı ile Vircell IgM + IgA testi göstermiştir. Geçirilmiş COVID-19 hastalarında ise en iyi uyumu 0.86 kappa katsayısı ile Abbott IgG ve 0.85 kappa katsayısı ile Dia.Pro IgG testi göstermiştir. IgM saptayan antikor testlerinin duyarlııklarının düşük olması nedeniyle rutin tanıda gerçek zamanlı revers transkriptaz polimeraz zincir reaksiyonu yerine tercih edilmemelidir. IgG saptayan testler ise, toplumsal seroprevalans ve özellikle terapötik immünplazma üretimi için COVID-19 geçirmiş kişilerde antikor yanıtını ve titrelerini saptamak için tercih edilebilir. Bununla birlikte, bu çalışmayı yürütenlerce SARS-CoV-2 IgC testleri için rutin kullanımda hem ECLIA/CLIA prensipli çalışan testler hem de EIA/ELISA prensipli testlerin birlikte kullanımının daha etkili olabileceği düşünülmektedir.

Anahtar kelimeler: COVID-19; IgA; IgG; IgM; SARS-CoV-2.

\section{ABSTRACT}

Following the emergence of severe acute respiratory syndrome coronavirus-2 (SARS CoV-2) and using only PCR for diagnosis, antibody tests have been rapidly developed by various commercial companies. There are differences between the sensitivity and specificity of these tests due to the usage of different viral target proteins and antibody subclasses. In order to evaluate the diagnostic use of these tests, we aimed to examine the diagnostic performance, especially sensitivity and specificity, of SARS-CoV-2 IgM, IgA and IgC tests of various companies (Abbott, Roche, Euroimmun, Dia.Pro, Anshlabs, Vircell, UnScience and RedCell), which have different principles (ECLIA/CLIA, EIA, LFA). Current $(n=180)$ and past $(n=180)$ COVID-19 patients with clinical and molecular diagnosis of COVID-19 admitted to Istanbul University-Cerrahpaşa, Cerrahpaşa Faculty of Medicine Hospital, Pandemic Polyclinic with suspected COVID-19 infection, were included in our study. The patients admitted within the first 3 weeks after the onset of symptoms were included in the current patient group, and those admitted at the third and after the third week were included in the past patient group. Serum samples $(n=180)$ obtained from Istanbul Sisli Hamidiye Etfal Training and Research Hospital, Blood Center between April and June 2018 before the COVID-19 pandemic were included in the study as a control group. All the tests included in our study were studied with the recommendations of the manufacturer companies. Between the $\lg G$ detection tests with different principles in patients with past COVID-19, the sensitivity and specificity values of the most effective tests were; $86.7 \% / 99.4 \%$ (Abbott), 86.1\%/98.9\% (Dia.Pro), 91.3\%/95\% (RedCell). Between the IgM detection tests with different principles in current COVID-19 patients, the sensitivity and specificity values were; $67.8 \% / 99.4 \%$ (Abbott), $68.9 \% / 98.6 \%$ (Vircell), 50\%/97.5\% (RedCell). Abbott IgM with a kappa coefficient of 0.67 and Vircell IgM $+\operatorname{IgA}$ test with a kappa coefficient of 0.65 showed the best fit in patients with current COVID-19 infection. In patients with past COVID-19, Abbott IgG with 0.86 kappa coefficient and Dia.Pro IgG test with 0.85 kappa coefficient showed the best match. Due to the low sensitivity of IgM detection antibody tests, they should not be preferred instead of real-time reverse transcriptase polymerase chain reaction in routine diagnosis. IgG detection tests may be preferred to detect the antibody response and the titers in people who have had COVID-19 for population seroprevalence and especially therapeutic immune plasma production. However, it is thought that the combined use of both ECLIA/CLIA-based and EIA/ELISA-based tests together may be more effective in routine use for SARS-CoV-2 IgG tests.

Keywords: COVID-19; $\lg A$; IgG; IgM; SARS-CoV-2. 


\section{Gíriş}

Çin'in Wuhan kentindeki deniz ürünü ve ıslak hayvan pazarıyla ilişkili ve etiyolojisi belirsiz pnömonilerle Aralık 2019'da başlayan salgının kaynağının yeni tipte bir koronavirüs olduğu anlaşılmıştır. Uluslararası virüs sınıflandırma komisyonu tarafından ciddi akut solunum sendromu koronavirüs-2 (SARS-CoV-2) olarak adlandırılan virüsün neden olduğu hastalık ise, Dünya Sağlık Örgütü (DSÖ) tarafından "coronavirus disease-2019" (COVID-19) olarak tanımlanmıştır ${ }^{1}$. SARS-CoV-2'nin dünyanın birçok ülkesine hızla yayılması ve COVID-19 olgularına bağlı ölümlerin artmasıyla birlikte DSÖ, 12 Mart 2020'de COVID-19 salgınını pandemi olarak ilan etmiştir ${ }^{2}$. SARS-CoV-2 ile enfekte hastaların klinik belirti ve bulguları atipik olmakla birlikte; öksürük, ateş, dispne ve viral pnömoni en sık görülen belirtilerdir. COVID-19'un klinik tanısı esas olarak epidemiyolojik öyküye, var olan klinik belirtilere, bilgisayarlı tomografi (BT) taramasına ve nükleik asit tespitine dayanmaktadır ${ }^{3}$. Serolojik testlerin doğrulama ve tanı amaçlı kullanımı henüz önerilmemekle birlikte, özellikle COVID-19'un seroprevalans temelli epidemiyolojisini anlamak için tarama ve aynı zamanda immün plazma tedavi amaçlı yaklaşımında immün yanıtın niteliği ve antikor niceliğini saptamak amaçlı kullanılabilir. Bu amaçlar doğrultusunda ticari firmalarca validasyonu tamamlanarak, toplum sağlığı için tarama ve bazen tanı amaçlı kullanıma sokulan farklı prensipli ticari antikor saptayan serolojik test kitlerinin performanslarının belirlenmesi çok önemlidir. COVID-19'a karşı yürütülen uluslararası ortak mücadelenin kazanılması ve optimize, etkin serolojik test kitlerinin elde edilmesi için ülkelere veya kıtasal bölgelere göre tanısal ve tarama performansların tespit edilmesi gereklidir. Bu çalışmada, COVID-19 klinik tanısı alan ve gerçek zamanlı revers transkriptaz polimeraz zincir reaksiyonu (rRT-PCR) temelli SARS-CoV-2 RNA test sonucu pozitif saptanan olgularla birlikte, COVID-19 salgınından önce farklı çalışmaların kontrol grubunu oluşturmak için etik kurallara uygun olarak alınan sağlıklı kan donörlerinin serumlarında; SARS-CoV-2 IgG, IgM ve IgA antikor yanıtlarını kalitatif ya da semikantitatif olarak saptayarak ticari farklı prensipli (kemilüminesans, enzim immunassay ve lateral flow assay) serolojik test kitlerinin tanı ve tarama performanslarını saptama amaçlanmıştır. Ayrıca, COVID-19 olgularının serokonversiyonuna dönük prensipleri farklı serolojik kitlerin etkinliği de değerlendirilmiştir.

\section{GEREÇ ve YÖNTEM}

Bu çalışma, T.C. Sağlık Bakanlığı Sağlık Hizmetleri Genel Müdürlüğü Bilimsel Araştırma Çalışmaları Komisyonu (Tarih: 29.05.2020), İstanbul Üniversitesi-Cerrahpaşa, Cerrahpaşa Tıp Fakültesi, Bilimsel Araştırma ve Değerlendirme Komisyonu (Tarih: 17.06.2020 ve Sayı: 73645) ve İstanbul Üniversitesi-Cerrahpaşa, Cerrahpaşa Tıp Fakültesi, Klinik Araştırmalar Etik Kurulu onayı ile gerçekleştirildi (Tarih: 09.07.2020 ve Karar No: 86928).

\section{Hastaların Seçimi ve Örneklerin Alınması}

Bu çalışmaya iÜC, CTF COVID-19 İlk Başvuru Polikliniğine COVID-19 şüphesiyle başvuran, klinik ve moleküler tanı almış ve bilgilendirilmiş gönüllü onamları alınan, 360 
hasta dahil edildi. Hastaların 180'i semptomların başlangıcından itibaren ilk üç hafta içerisinde, diğer 180'i ise semptomların başlamasından üçüncü hafta ve sonrasında olacak şekilde çalışma gruplarına dahil edildi. Kontrol grubu olarak, COVID-19 pandemisi öncesinde alınan (Nisan-Haziran 2018) 180 (8 kadın, 172 erkek; yaş ort.=46.3) serum örneği Şişli Hamidiye Etfal Eğitim ve Araştırma Hastanesi, Kan Merkezinden temin edildi. Hastaların ilk başvuru zamanı, PCR pozitiflik tarihi, belirti başlangıç zamanı ve kronik hastalık varlığı sorgulanarak kaydedildi. Hastaların demografik verileri geriye dönük olarak iÜC, CTF Hastanesinin Doktor ve Laboratuvar Bilgilendirme Sisteminden elde edildi. SARSCoV-2 antikor tayini için hastalardan alınan serum örnekleri uygun transport koşullarında laboratuvara ulaştırıldı. Serum örnekleri çalışılana kadar $-80^{\circ} \mathrm{C}^{\prime}$ de muhafaza edildi. Akut COVID-19 olgularının 73'ü kadın 107'si erkek olup, yaş ortalaması 40.1'dir. Geçirilmiş COVID-19 olgularının ise 85'i kadın 95'i erkek olup, yaş ortalaması 41.4'dür. Çalışmanın hasta ve kontrol grupları sadece yaş ortalaması açısından benzerdir ( $p>0.05$ ).

\section{Çalışılan Ticari Antikor Testleri}

Araştırmaya alınan ECLIA/CLIA, EIA ve LFA ticari kitleri hizmet sunan firmalardan temin edilmiştir. Buna göre, akut COVID-19 hastası ve kontrol grubundan alınan serum örneklerinde açık tam otomatize sistemde (Triturus, Grifols, İspanya) Euroimmun slgA, Euroimmun NCP IgM, Dia.Pro lgM, Vircell IgM + IgA, Anshlabs IgM ve kapalı tam otomatize sistemde (Architect i1000SR, Abbott, ABD) Abbott IgM testleri çalışıldı. Geçirilmiş COVID-19 hastaları ve kontrol grubundan alınan serum örneklerinde ise, açık tam otomatize sistemde (Triturus, Grifols, İspanya) Euroimmun slgG, Euroimmun NCP IgM, Dia.Pro IgG, Vircell IgG, Anshlabs IgG ve kapalı tam otomatize sistemde (Cobas e 601 analizörü, Roche, Almanya ve Architect i1000SR, Abbott, ABD) Roche Total Ab ve Abbott IgG testleri çalışıldı. Bununla birlikte; 80 akut, 80 geçirilmiş COVID-19 hastasında immünokromatografik yöntem ile UnSciense lgM + IgG ve RedCell lgM + IgG hızlı kart testleri çalışıldı. Roche Total Ab testi hariç tüm testler iÜC, CTF Mikrobiyoloji Laboratuvarı Seroloji Biriminde üretici firmaların prospektüsünde belirtilen öneriler doğrultusunda çalışılarak kalitatif ve semikantitatif sonuçlar elde edildi. Roche Total Ab testi ise İstanbul Şişli Hamidiye Etfal Kan Merkezinde üretici firmaların önerileri doğrultusunda çalışıldı. Farklı antijenik belirteçleri kullanan testlerle ilgili detaylı bilgiler Tablo I'de yer almaktadır.

\section{İstatistiksel Analiz}

İstatistiksel değerlendirme, IBM SPSS 20.0 (IBM Corp., Armonk, NY, ABD) paket programı ve Microsoft Excel versiyon 2013 ile yapıldı. Toplanan verilerin analizinde frekans (n), yüzde (\%) ve ortalama değerleri belirlendi. Duyarlılık, özgüllük, pozitif prediktif değer (PPD), negatif prediktif değer (NPD), olası olma "likelihood" ve doğruluk değerleri hesaplandı. rRT-PCR ve antikor testleri arasındaki uyum düzeyini değerlendirmek için Cohen'in kappa katsayısı kullanıldı; uyumda > 0.6 temel alındı. Test duyarlılığının hesaplanmasında sınırdaki sonuçlar negatif olarak kabul edildi. $\mathrm{p}<0.05$ anlamlı olarak kabul edildi. 
ปั

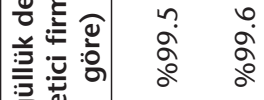

:

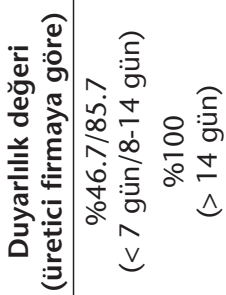

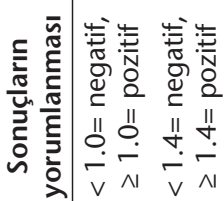

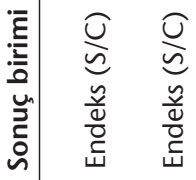

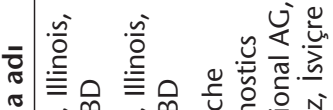

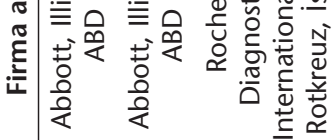

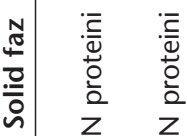

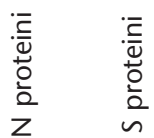

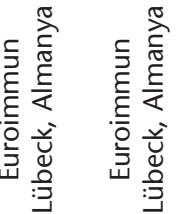

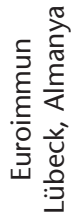

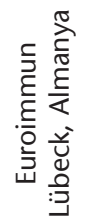

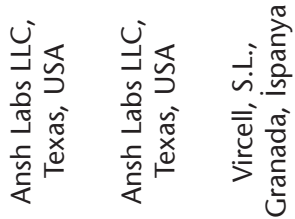

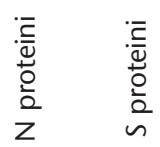

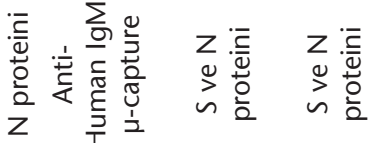

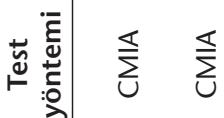

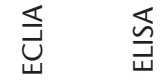

$\frac{\nwarrow}{\varpi}$

$\underset{\Xi}{\varpi}$

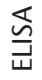

岀至 $\quad \frac{\nwarrow}{\exists}$

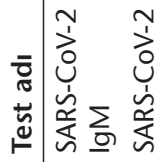

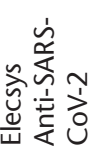

ஸे⿺尢丶 Ũ

ஸ் ப்

出的市

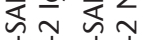

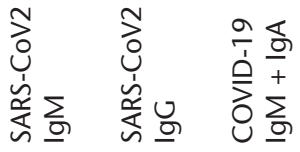




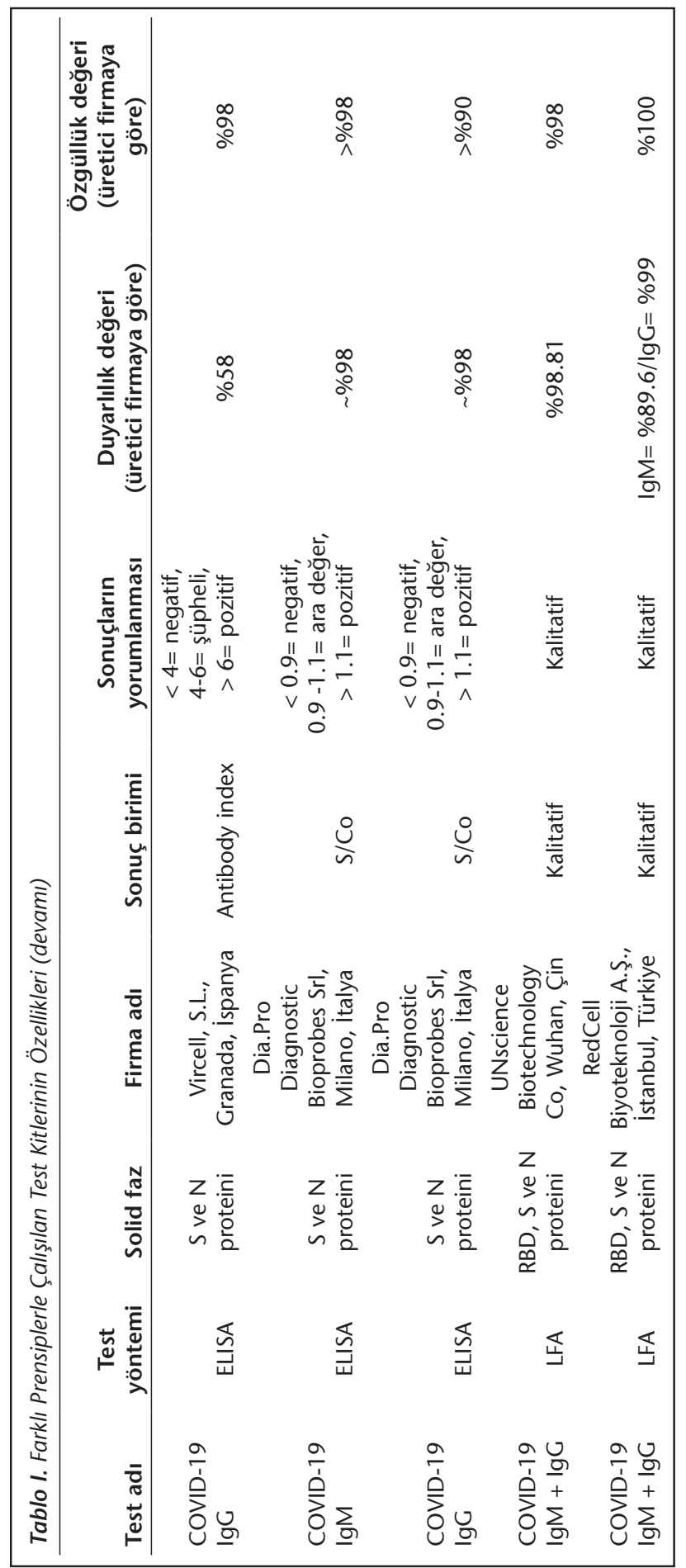




\section{BULGULAR}

Akut COVID-19 hastalarında kemilüminesans yöntem ile çalışılan tek test olan Abbott SARS-CoV-2-lgM testinin duyarlılığı ve özgüllüğü sırasıyla \%67.8 ve \%99.4 olarak saptanmıştır. ELISA prensipli testler arasında S protein temelli Euroimmun IgA testinin duyarlıık ve özgüllük oranları sırasıyla \%61.7 ve \%91.5 idi. N protein temelli Euroimmun IgM testi ise, \%35.6 duyarlılık ve \%99.4 özgüllük göstermiştir. S ve N protein temelli testler arasında Vircell lgM + IgA testi \%68.9 duyarlılık ve \%98.6 özgüllük ile en etkili test olarak saptanmıştır. İmmünokromatografi temelli hızlı testlerde ise, RedCell IgM testi \%50 duyarlılık ve \%97.5 özgüllükle en etkili test olarak bulunmuştur (Tablo II). ELISA ve kemilüminesans prensipli testler, akut hastalarda PCR pozitiflik tarihine göre değerlendirildiğinde ikinci haftadan itibaren duyarlıığın daha yüksek olduğu görülmüş ve Anshlabs IgM testi hariç istatistiksel olarak anlamlı derecede yüksek bulunmuştur (Tablo III). Akut COVID-19 hastalarında en iyi uyumu 0.67 kappa katsayısı ile Abbott IgM ve 0.65 kappa katsayısı ile Vircell IgM + IgA testi göstermiştir.

Geçirilmiş COVID-19 hastalarında kemilüminesans prensipli $N$ protein temelli Roche Elecysis Anti-SARS-CoV-2 (Total Ab) ile Abbott SARS-CoV-2 lgG testlerinin özgüllükleri aynı olup (\%99.4), duyarlılık açısından Abbott SARS-CoV-2 IgG testi daha etkili (\%86.7) bulunmuştur. ELISA prensipli testler arasında, S protein temelli Euroimmun IgG testinin duyarlılık ve özgüllük oranları sırasıyla, $\% 80.6$ ve $\% 98.9$ bulunmuştur. $N$ protein temelli Euroimmun IgM testi ise, \%76.7 duyarlılık ve \%98.1 özgüllük göstermiştir. S ve N proteinlerini hedef alan Dia.Pro SARS-CoV-2 lgG testi \%86.1 duyarlıık ve \%98.9 özgüllük ile en etkili test olarak saptanmıştır. İmmünokromatografi temelli hızlı testlerde ise RedCell COVID-19 IgG testi \%91.25 duyarlılık ve \%95 özgüllükle en etkili test olarak saptanmıştır (Tablo IV). ELISA ve kemilüminesans prensipli testler, geçirilmiş hastalarda PCR pozitiflik tarihine göre değerlendirildiğinde üçüncü haftada duyarlılığın daha yüksek olduğu görülmüştür (Tablo V). Geçirilmiş COVID-19 hastalarında en iyi uyumu 0.86 kappa katsayısı ile Abbott IgG ve 0.85 kappa katsayısı ile Dia.Pro IgG testi göstermiştir.

Akut ve geçirilmiş COVID-19 hastalarında çalışılan örneklerin spesifikasyonunda her test için ROC eğrileri Şekil 1 ve 2'de verilmiştir. Çalışılan tüm testlerin duyarlıık, özgüllük, PPD, NPD, pozitif likelihood, negatif likelihood ve doğruluk değerleri Tablo II ve IV'te ayrıntılı olarak verilmiştir.

\section{TARTIŞMA}

COVID-19 enfeksiyonunun erken ve doğru tanısı, hastaların uygun tedaviye başlayabilmesi için önemli olmakla birlikte özellikle asemptomatik veya hafif semptomatik hastalarda virüsün toplum içindeki yayılımını engellemek için oldukça önemlidir. Günümüzde SARS-CoV-2 enfeksiyonunun mikrobiyolojik tanısı için solunum yolu örneklerinden gerçek zamanlı ters transkripsiyon polimeraz zincir reaksiyonu (rRT-PCR) yöntemine dayanan moleküler testler kullanılmaktadır ${ }^{4-6}$. Moleküler testler yüksek özgüllükleri nedeniyle genelde doğrulama amaçlı kullanılırken, SARS-CoV-2 enfeksiyonunda tarama amaçlı ve altın standart olarak kullanılmaktadır. Ancak SARS-COV-2 tanısında klinik örneğin türü ve alınma şekli, 


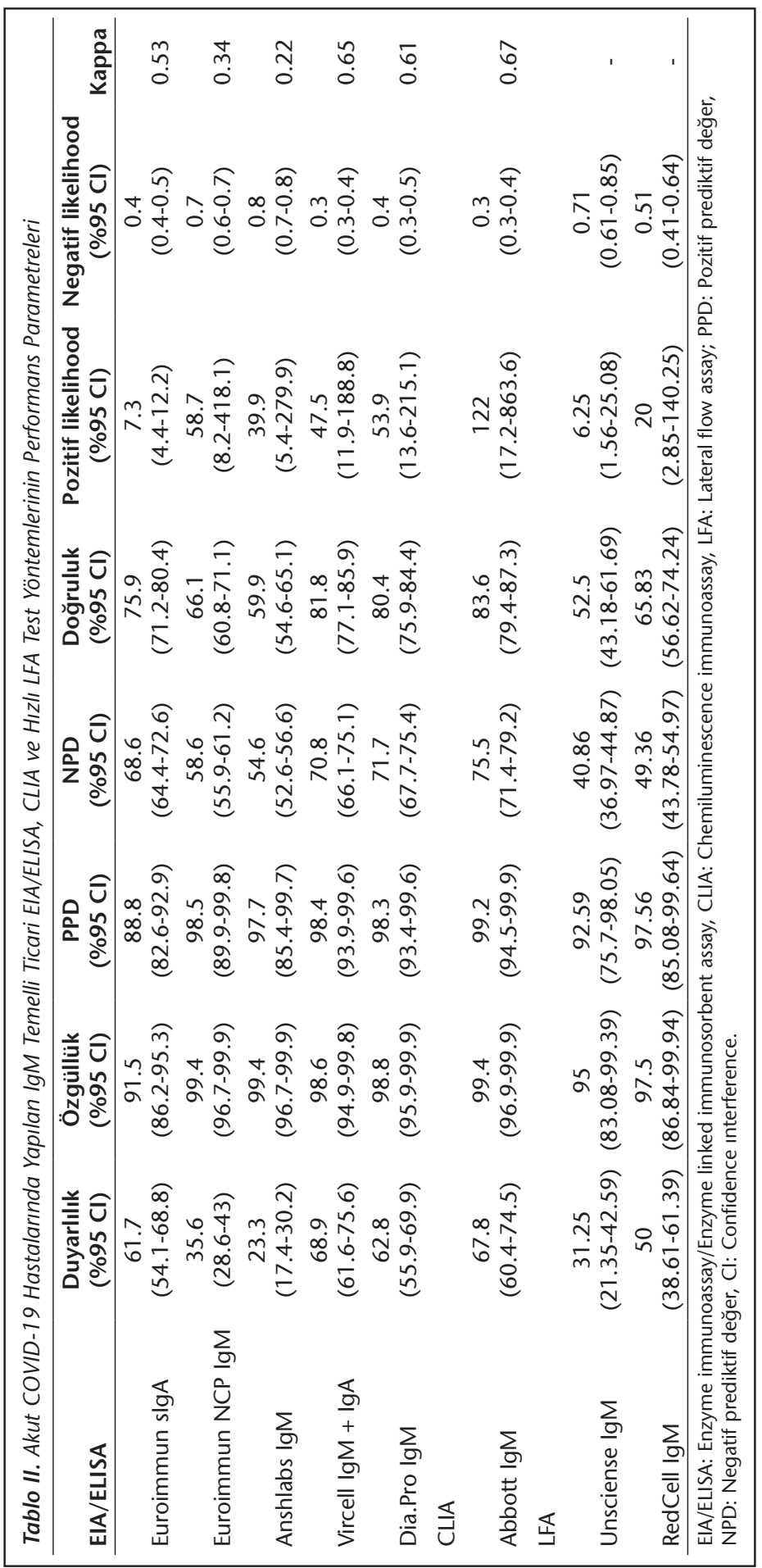


Tablo III. Akut COVID-19 Hastalarından Alınan Serumlarda Çalışılan Testlerin Haftalara Göre Duyarlııkların (\%) Değerlendirilmesi

\begin{tabular}{|c|c|c|c|c|c|}
\hline EIA/ELISA & $\begin{array}{c}1 \mathrm{~h}(0-7) \\
\mathrm{n}=51, \%\end{array}$ & $\begin{array}{l}2 h(8-14) \\
n=72, \%\end{array}$ & $\begin{array}{c}3 \mathrm{~h}(15-21) \\
\mathrm{n}=57, \%\end{array}$ & $\begin{array}{c}\text { Toplam } \\
n=180, \%\end{array}$ & $p$ \\
\hline Euroimmun slgA & 37.3 & 63.9 & 80.7 & 61.7 & $<0.001$ \\
\hline Euroimmun NCP IgM & 15.7 & 44.4 & 42.1 & 35.6 & $<0.001$ \\
\hline Anshlabs IgM & 17.6 & 25.0 & 26.3 & 23.3 & 0.518 \\
\hline Vircell $\lg M+\lg A$ & 37.3 & 80.6 & 82.5 & 68.9 & $<0.001$ \\
\hline Dia.Pro IgM & 29.4 & 73.6 & 78.9 & 62.8 & $<0.001$ \\
\hline \multicolumn{6}{|l|}{ CLIA } \\
\hline Abbott IgM & 29.4 & 75 & 93 & 67.8 & $<0.001$ \\
\hline
\end{tabular}

transport ve saklama koşulları, hastalığın evresi ve klinik tablosu gibi birçok faktör rRT-PCR testlerinin duyarlıı̆ı̆ı etkilemektedir. Bununla birlikte, RNA testlerinin veriminin düşük olması, örnek hazırlama prosedürü için tecrübeli personele ihtiyaç duyulması, biyogüvenlik açısından uygun laboratuvar koşullarının sağlanması sınırlayıcı diğer faktörler arasındadır. Enfeksiyon etkenlerinin tanısında sıklıkla tarama amaçlı kullanılan seroloji temelli testlerin, SARS-COV-2 enfeksiyonu için kullanımı tartışmalı bir konudur. Bununla birlikte, COVID-19 tanısında tamamlayıcı bir testtir ve salgının ikinci aşamasında epidemiyolojik çalışma için gerekli olan stratejik bir araçtır. Bu çalışmada, piyasada ticari olarak bulunan farklı prensiplere sahip SARS-COV-2 IgA, IgM ve lgG saptayan antikor testlerinin performansını değerlendirme amaçlanmıştır. Türkiye'den ilk kez bildirilecek olan bu çalışmadaki verilerin, SARS-COV-2 enfeksiyonunun tanı ve takibine yönelik bir bakış açısı sunacağı kanaati bulunmaktadır.

Kemilüminesans yöntemine dayanan Roche Total Ab ve Abbott SARS-CoV-2 lgG testleriyle yapılan bir çalışmada, duyarlııı oranları sırasıyla \%90.4 (\%95 Cl: 81.2-96.1) ve \%82.2 (\%95 Cl: 71.5-90.2) olarak saptanmıştır. Bununla birlikte, PCR pozitiflik tarihinden itibaren dördüncü haftadan sonra alınan serum örneklerinde artan duyarlılık gösterilmiştir $^{7}$. Naaber ve arkadaşları ${ }^{8}$ tarafından 97 COVID-19 hastası ile yapılan bir çalışmada Roche \%83.5, Abbott ise \%84.5 duyarlılık göstermiş olup, her iki testte de \%100 özgüllük saptanmıştır. PCR pozitif 45 COVID-19 hastasında yapılan bir diğer çalışmada ise Roche \%75.6 ve Abbott \%77.8 duyarlılık göstermiş olup, özgüllükleri sırasıyla \%97 ve \%100 olarak saptanmıştır ${ }^{9}$. Bizim çalışmamızda da Roche \%79.3, Abbott \%86.7 duyarlılık göstermiş olup, her iki testte özgüllük oranı \%99.4 olarak saptanmıştır. Kemilüminesans yöntemine dayanan testler arasında en etkili olarak Abbott IgG testi saptansa da aynı firmaya ait IgM test duyarlılık oranının (\%68.14) düşük olduğu görülmüştür.

Bu çalışmada enzim immunassay (EIA) yöntemine dayanan testler değerlendirildiğinde; genel olarak IgM saptayan testlerin duyarlılıklarının, IgG saptayan testlere göre daha düşük olduğu görülmektedir. Buna karşın, akut hastalarda Vircell IgM + IgA testi \%68.9 duyarlııı ve \%98.6 özgüllük ile en etkili test olarak saptanmıştır. Hem S ile $\mathrm{N}$ protein temelli olmasının, hem de IgA ile IgM antikorlarını saptayabilmesinin test duyarlılığını 


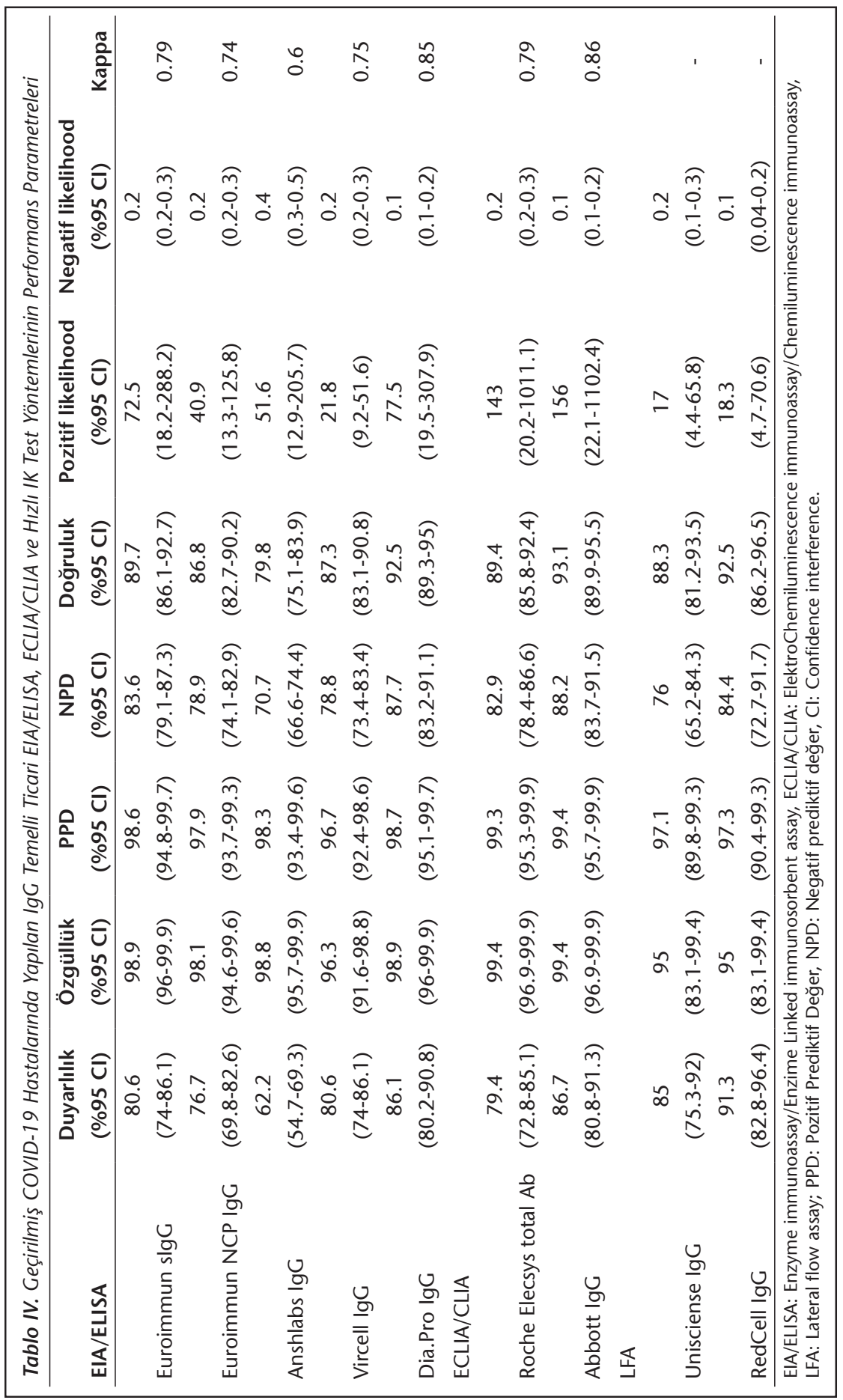




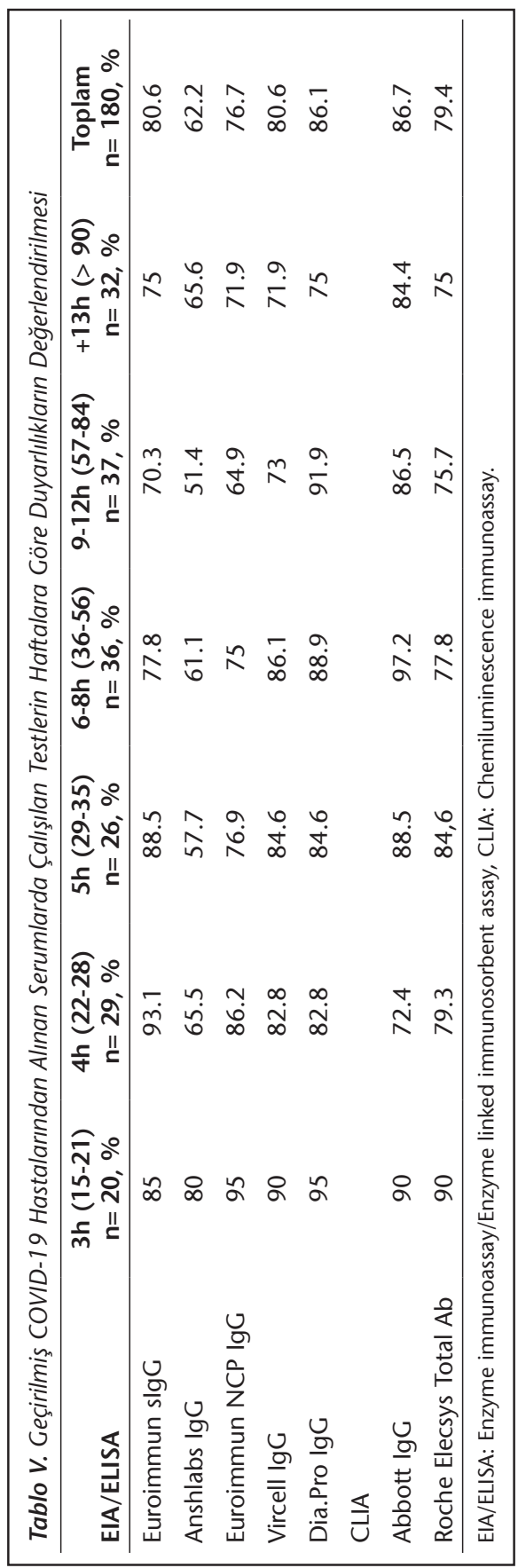




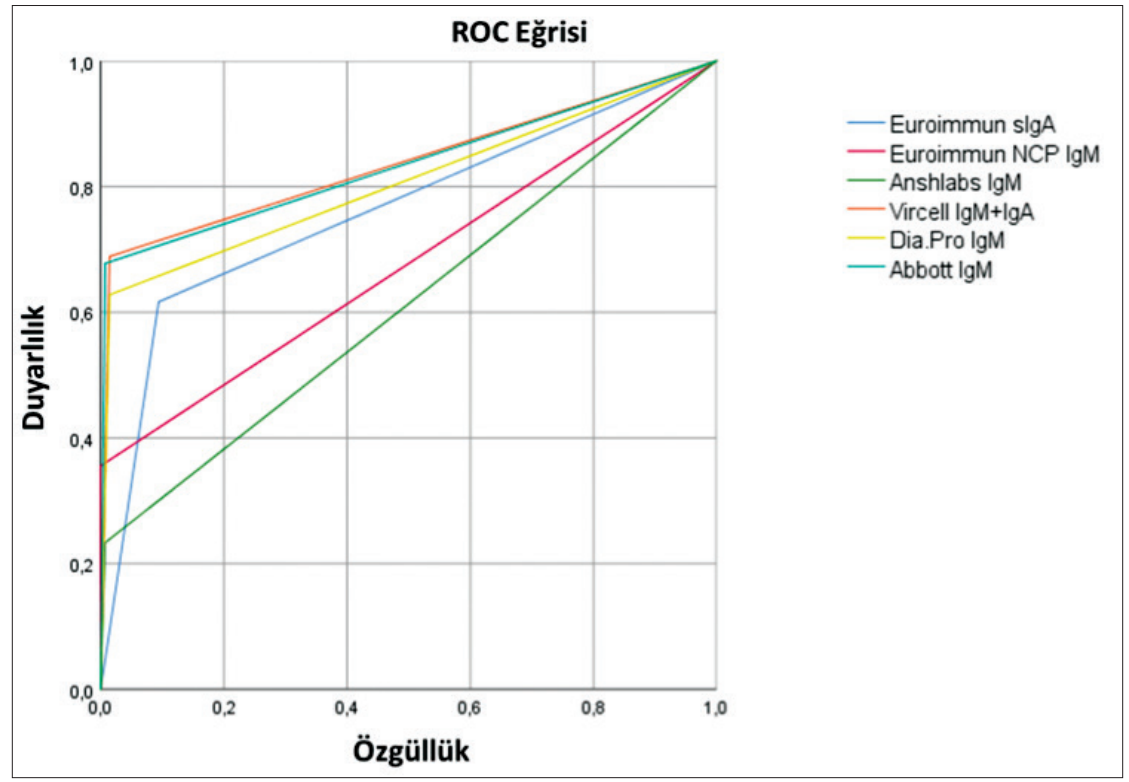

Şekil 1. Akut COVID-19 hastalarında farklı prensipli antikor testlerinin ROC analizi.

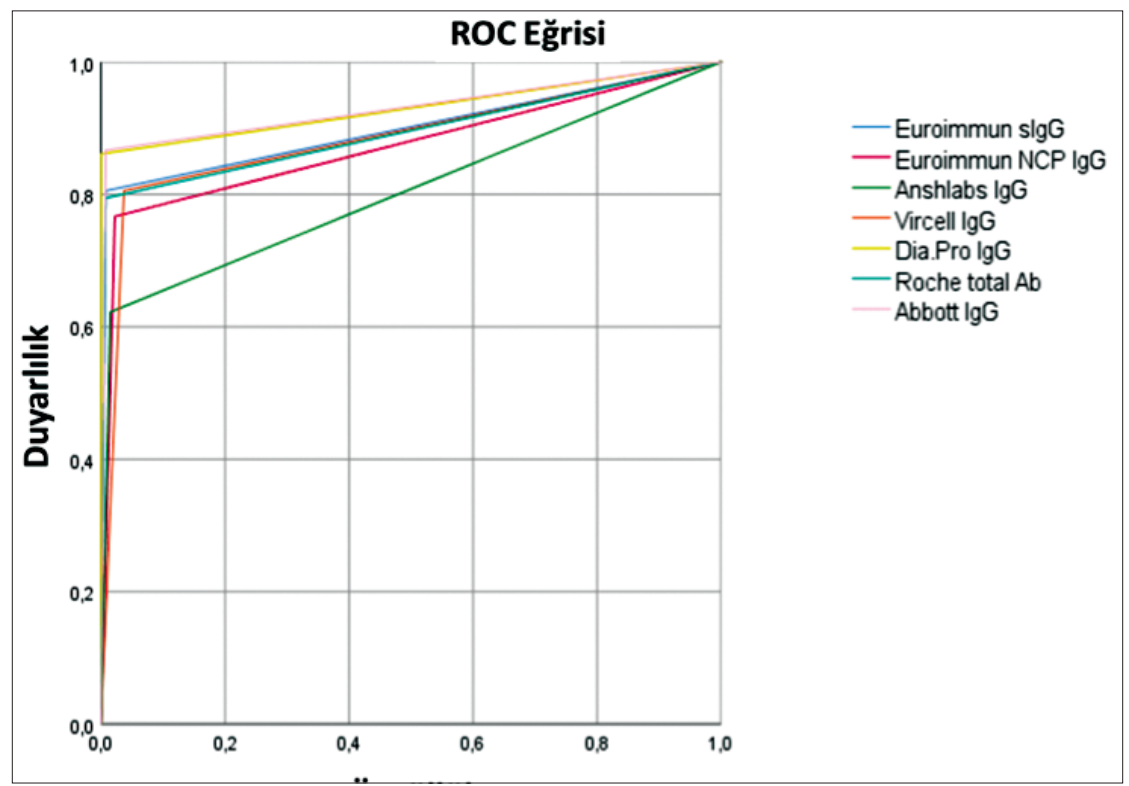

Şekil 2. Geçirilmiş COVID-19 hastalarında farklı prensipli antikor testlerinin ROC analizi.

olumlu yönde etkilediği düşünülmektedir. Brezilya'dan yapılan bir çalışmada, Vircell IgM + IgA testinin duyarlılığı \%90.2 (84.9-93.8) olarak saptanırken Vircell IgG testinde duyarlılık \%76.8 (70.0-82.5) olarak bulunmuştur ${ }^{10}$. Yine aynı çalışmada Euroimmun IgA 
duyarlılığı \%76.1 (67.1-83.1) iken, Euroimmun IgG (spike) duyarlılığı \%58.7 (49.3-67.5) olarak bulunmuştur ${ }^{10}$. İncelenebildiği kadarıyla antikor testleri arasında en sık Euroimmun IgG (spike) çalışılmış olup, çeşitli çalışmalarda duyarlılıkları \%70.7 ila \%83.6 arasında olduğu görülmektedir ${ }^{7-9,11,12}$. Yassine ve arkadaşları ${ }^{13}$ yapmış oldukları çalışmada Dia. Pro COVID-19 IgG testinin duyarlıı̆̆ını \%66.3 olarak saptarken, bu çalışmada \%86.1 (80.2-90.8) duyarlııkla en etkili test olarak saptanmıştır. Bu çalışmada kullanılan kitlerle ilgili benzer çalışmaların karşılaştırmalı verileri Tablo $\mathrm{VI}^{\prime}$ da sunulmuştur.

Elde edilen bulgulardan yola çıkarak; ELISA prensipli testler için, SARS-CoV-2'nin N ve $S$ proteinlerine özgü antikorları tespit etmedeki duyarlıığın, sadece $S$ proteinine özgü IgA veya lgG'yi tespit eden testlerden daha yüksek olduğu görülmektedir.

LFA testleri değerlendirildiğinde, diğer yöntemlere kıyasla duyarlılık oranlarının düşük olduğu bulunmuştur. Bununla birlikte, çalışmaya dahil edilen her iki ticari kitte de IgM tespit duyarlıı̆̆ının IgG'ye göre daha düşük olduğu görülmüştür. Kolay ve hızlı performansları nedeniyle özellikle de işyerlerinde yaygın kullanımı olan LFA testlerinin kanıtlanmış duyarlıık ve özgüllükleri bulunmamaktadır ${ }^{14}$ bu nedenle tek başına kullanılması önerilmemektedir ${ }^{15}$.

Bu çalışmada yer alan kitlerin duyarlılığı, yapılan çalışmalarla kıyaslandığında farklılık gösterebilir ancak özgüllükleri benzerdir. Duyarlııklarındaki bu farklılığın çalışmamıza dahil edilen COVID-19 hastalarının klinik tablo ve/veya komorbidite durumlarına bağlı olarak değişebilen immün yanıttan kaynaklı olabileceği düşünülmektedir. Yapılan bir çalışmada, COVID-19 hastalığını hafif semptomatik geçiren kişilerde 14. güne kadar \%72'sinde SARSCoV-2 IgM ve \%83'ünde SARS-CoV-2 IgA ve yanıtı geliştirirken, \%95'i SARS-CoV-2 IgG yanıtı (30. gün \%100) geliştirdiği gösterilmiştir ${ }^{16}$. Asemptomatik kişilerde ise 14. günde \%20'sinde SARS-CoV-2 IgA, \%22'sinde SARS-CoV-2 IgM yanıtı ve enfeksiyondan sonraki 30. günde ise $\% 45$ 'inde SARS-CoV-2 lgG yanıtı geliştiğinin gösterilmiş olması bu düşünceyi desteklemektedir. Bununla birlikte özellikle lgG için, PCR pozitifliğinden 4 hafta sonra alınan serum örneklerinde 2-3. haftaya kıyasla pozitiflik oranlarının daha yüksek olduğu görülmüştür ${ }^{7}$. Her ne kadar bu çalışma hastaların serokonversiyon takibine yönelik olmasa da, antikor testlerinin tanısal performanslarının IgM için ikinci haftada, IgG için ise üçüncü haftada daha etkili olduğunu gözlemlenmiştir. Benzer şekilde, Kohmer ve arkadaşlarının ${ }^{17}$ yapmış olduğu bir çalışmada, enfeksiyonun erken fazı için (5-9. gün) duyarlılık \%58.8 ile \%76.5 arasında saptanırken, ileriki dönemde (10-18. gün) \%93.8 ile \%100 arasında değiştiği gösterilmiştir. Çin'de yapılan bir çalışmada ise, hastalığın başlamasından sonra IgG için ortalama serokonversiyon süresinin 11 gün (8-16 gün), IgM için ise 14 gün (8-28 gün) olduğu gösterilmiştir ${ }^{18}$.

Serolojik test kapsamında validasyonları tamamlanarak ticari kullanıma giren tüm serolojik test kitleri arasından araştırmamızdaki ECLIA/CLIA temelli iki firma (Roche, İsveç ve Abbott, ABD) dışında, diğer firmaların da (Siemens, Almanya) davet edilmesine karşın yanıt alınamadığından dolayı bu çalışmaya dahil edilememiştir. Bu durum, yapılan çalışmanın kısıtııı̆ı olarak görülmekle birlikte, çeşitli firmalardan bu serolojik testlerin sadece araştırma amaçlı alınmasına bağlı olarak temin edilen kitlerin kısıtlı sayıda olmasından dolayı çok fazla sayıda olgu-kontrol örneklerinin çalışılamaması bir diğer sınırlayıcı unsurdur. 


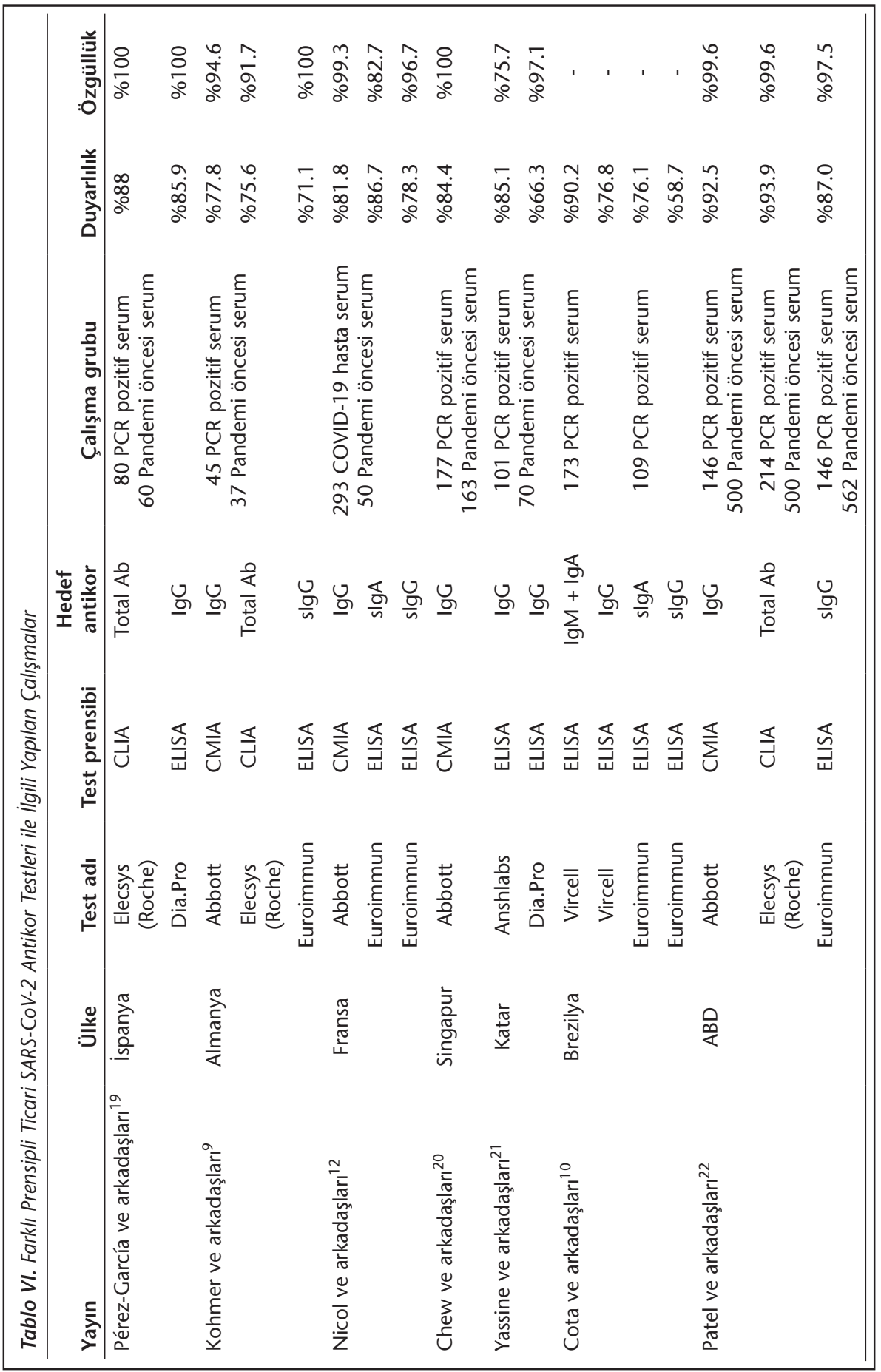


Sonuç olarak, SARS-CoV-2'nin mikrobiyolojik olarak rutin tanısında bugün moleküler yöntemler kullanılsa da serolojik yöntemleri toplumsal seroprevalans (asemptomatik veya semptomatik tanı) ve özellikle terapötik immünplazma üretimi için COVID-19 geçirilmiş ya da aşı olan kişilerde IgG nötralizan antikor yanıtı ve titreleri saptamak için tercih edilebilir. SARS-CoV-2 IgG testlerinin tıbbi mikrobiyoloji laboratuvarlarında, COVID-19 ilintili hastalara dönük rutin hizmet amaçlı kullanımlarında, hastalara olan test maliyeti ve tarama amaçlı performanslarının bugünkü validasyon performansları ile EIA/ELISA yöntemlerinin ve özellikle "rastgele erişim/STAT" girişli otomatik kapalı analizörlerde uygulanabilirliği ile özgün test tekniğinden (paramanyetik mikropartikül solid fazdaki antijenin saptanacak antikor ile bağlanmasını tespit eden lüminesans molekülle işaretli konjugatsubstrat reaksiyonuna dayalı olarak gelişen sinyalin ölçümü) dolayı birlikte bulundurulmalarını önermekteyiz. Ayrıca ikili test sistemini ekonomik nedenlerle bulunduramayan ve sadece tek test sistemini bulunduran merkezlerde kullanılan tek test ile sonucu şüpheli veya negatif bulunan kişilerde ise, en az 14-21 gün sonra bu test sistemi ile serokonversiyonun izlenmesi yararlı olabilir.

Akut hastaların serolojik tanısı için moleküler yöntem olarak PCR'nin kullanılmadığı, PCR kit temininin yapılamadığı kısa süreli acil veya herhangi özel durumlarda (atipik olgular, klinisyenin özel talebi doğrultusunda ya da bilimsel araştırmalarda) IgM ya da IgA saptayan testlerin kullanımı önerilebilir. Ancak, rutin tanıda duyarlılıklarının düşük olması nedeniyle tercih edilmemesi gerektiğini düşünmekteyiz. Tercih edilmesi durumunda ise; SARS-CoV-2 enfeksiyonuna karşı konak immün yanıtta ilk gelişen antikorlar $\mathrm{N}$ antijenine özgü olduğundan dolayı, akut enfeksiyonun serolojik tanısında kullanılan antijenik hedefe dikkat edilmelidir. COVID-19 pandemisinde birinci yılın tamamlandığı bu süreçte halen gerçek antikor pozitifliğinin koruyucu bağışıkığına yönelik etkisi tartışmalı bir konu olmakla birlikte henüz kesin bir veri yoktur. Bu nedenle, antikor testlerine karşı her zaman temkinli yaklaşılmalı ve bağışıklık göstergesi olarak henüz kabul edilmemelidir.

\section{ETIK KURUL ONAYI}

Bu çalışma, T.C. Sağlık Bakanlığı Sağlık Hizmetleri Genel Müdürlüğü Bilimsel Araştırma Çalışmaları Komisyonu (Tarih: 29.05.2020), İstanbul Üniversitesi-Cerrahpaşa, Cerrahpaşa Tıp Fakültesi, Bilimsel Araştırma ve Değerlendirme Komisyonu (Tarih: 17.06.2020 ve Sayı: 73645) ve İstanbul Üniversitesi-Cerrahpaşa, Cerrahpaşa Tıp Fakültesi, Klinik Araştırmalar Etik Kurulu onayı ile gerçekleştirildi (Tarih: 09.07.2020 ve Karar No: 86928).

\section{ÇIKAR ÇATIŞMASI}

Yazarlar bu makale ile ilgili herhangi bir çıkar çatışması bildirmemişlerdir.

\section{KAYNAKLAR}

1. Zhou P, Yang XL, Wang XG, Hu B, Zhang L, Zhang W, et al. A pneumonia outbreak associated with a new coronavirus of probable bat origin. Nature 2020; 579(7798): 270-73.

2. World Health Organization (WHO). Available from: https://www.who.int/dg/speeches/detail/whodirector-general-s-opening-remarks-at-the-mission-briefing-on-covid-19---12-march-2020. (Accessed date: 21.03.2021) 
3. Li X, Geng M, Peng Y, Meng L, Lu S. Molecular immune pathogenesis and diagnosis of COVID-19. J Pharm Analysis 2020; 10(2): 102-8.

4. Favresse J, Eucher C, Elsen M, Marie T-H, Dogné J-M, Douxfils J, et al. Clinical performance of the Elecsys electrochemiluminescent immunoassay for the detection of SARS-CoV-2 total antibodies. Clin Chem 2020; 66(8): 1104-6.

5. Tang MS, Hock KG, Logsdon NM, Hayes JE, Gronowski AM, Anderson NW, et al. Clinical performance of two SARS-CoV-2 serologic assays. Clin Chem 2020; 66(8): 1055-62.

6. Tang MS, Hock KG, Logsdon NM, Hayes JE, Gronowski AM, Anderson NW, et al. Clinical Performance of the Roche SARS-CoV-2 Serologic Assay. Clin Chem 2020; 66(8): 1107-9.

7. Schnurra C, Reiners N, Biemann R, Kaiser T, Trawinski H, Jassoy C. Comparison of the diagnostic sensitivity of SARS-CoV-2 nucleoprotein and glycoprotein-based antibody tests. J Clin Virol 2020; 129: 104544.

8. Naaber P, Hunt K, Pesukova J, Haljasmägi L, Rumm P, Peterson P, et al. Evaluation of SARS-CoV-2 IgG antibody response in PCR positive patients: Comparison of nine tests in relation to clinical data. PloS One 2020; 15(10): e0237548.

9. Kohmer N, Westhaus S, Rühl C, Ciesek S, Rabenau HF. Brief clinical evaluation of six high-throughput SARSCoV-2 lgG antibody assays. J Clin Virol 2020; 104480.

10. Cota G, Freire ML, de Souza CS, Pedras MJ, Saliba JW, Faria V, et al. Diagnostic performance of commercially available COVID-19 serology tests in Brazil. Int J Inf Dis 2020; 101: 382-90.

11. Jääskeläinen AJ, Kuivanen S, Kekäläinen E, Ahava MJ, Loginov R, Kallio-Kokko $H$, et al. Performance of six SARS-CoV-2 immunoassays in comparison with microneutralisation. J Clin Virol 2020; 129: 104512.

12. Nicol T, Lefeuvre C, Serri O, Pivert A, Joubaud F, Dubée V, et al. Assessment of SARS-CoV-2 serological tests for the diagnosis of COVID-19 through the evaluation of three immunoassays: Two automated immunoassays (Euroimmun and Abbott) and one rapid lateral flow immunoassay (NG Biotech). J Clin Virol 2020; 129: 104511.

13. Yassine HM, Al-Jighefee H, Al-Sadeq DW, Dargham SR, Younes SN, Shurrab F, et al. Performance evaluation of five ELISA kits for detecting anti-SARS-COV-2 IgG antibodies. Int J Inf Dis 2020; 102: 181-7.

14. Lassaunière R, Frische A, Harboe ZB, Nielsen AC, Fomsgaard A, Krogfelt KA, et al. Evaluation of nine commercial SARS-CoV-2 immunoassays. J Medrxiv 2020.

15. Serrano MM, Rodríguez DN, Palop NT, Arenas RO, Córdoba MM, Mochón MDO, et al. Comparison of commercial lateral flow immunoassays and ELISA for SARS-CoV-2 antibody detection. J Clin Virol 2020; 129: 104529.

16. Shirin T, Bhuiyan TR, Charles RC, Amin S, Bhuiyan I, Kawser Z, et al. Antibody responses after COVID-19 infection in patients who are mildly symptomatic or asymptomatic in Bangladesh. Int J Inf Dis 2020; 101: 220-5.

17. Kohmer N, Westhaus S, Rühl C, Ciesek S, Rabenau HF. Clinical performance of different SARS-CoV-2 IgG antibody tests. J Med Virol 2020; 92(10): 2243-7.

18. Qu J, Wu C, Li X, Zhang G, Jiang Z, Li X, et al. Profile of immunoglobulin G and IgM antibodies against severe acute respiratory syndrome coronavirus 2 (SARS-CoV-2). Clin Infect Dis 2020; 71(16): 2255-8.

19. Perez-Garcia F, Perez-Tanoira R, Iglesias ME, Romanyk J, Arroyo T, Gomez-Herruz P, et al. Comparative evaluation of six immunoassays for the detection of antibodies against SARS-CoV-2. J Virol Methods 2021; 289: 114047.

20. Chew KL, Tan SS, Saw S, Pajarillaga A, Zaine S, Khoo C, et al. Clinical evaluation of serological IgG antibody response on the Abbott Architect for established SARS-CoV-2 infection. J Clin Microbiol 2020; 26(9): 1256. e9-1256.

21. Yassine HM, Al-jighefee H, Al-Sadeq DW, Dargham SR, Younes SN, Shurrab F, et al. Performance evaluation of five ELISA kits for detecting anti-SARS-COV-2 IgG antibodies. Inter J of Inf Dis 2021; 102: 181-7.

22. Patel EU, Bloch EM, Clarke W, Hsieh Y-H, Boon D, Eby Y, et al. Comparative performance of five commercially available serologic assays to detect antibodies to SARS-CoV-2 and identify individuals with high neutralizing titers. J Clin Microbiol 2021; 59(2): e02257-20. 